\title{
Residential buildings with heat pumps peak power reduction with high performance insulation
}

\author{
Henri Sarevet ${ }^{1, *}$, Jevgeni Fadejev ${ }^{1}$, Martin Thalfeldt ${ }^{1}$, and Jarek Kurnitski ${ }^{1,2}$ \\ ${ }^{1}$ Tallinn University of Technology, Department of Civil Engineering and Architecture, Ehitajate tee 5, 19086, Tallinn, Estonia \\ ${ }^{2}$ Aalto University, School of Engineering, Rakentajanaukio 4 A, FI-02150 Espoo, Finland
}

\begin{abstract}
Revised EPBD directive has set ambitious targets for nearly zero energy buildings. In residential buildings, energy performance can be improved mainly by applying better insulation of building fabric and by efficient energy sources, i.e. heat pumps. Electricity use and peak powers will increase when heat pumps, both air to water and ground source heat pumps, are used for heat source in new residential buildings compared to heating solutions that do not use electricity. The purpose of this study was to determine how much the high performance thermal insulation can compensate the increase of electricity use and peak power caused by extensive application of heat pumps in Finland residential buildings. The present study used five residential buildings that describe residential newbuild market. Finnish regulation defines minimum insulation level and high performance insulation level which were applied to single family houses, terraced house and apartment buildings to simulate electric power values all year round. Hourly electrical power values were simulated with dynamic simulation software IDA ICE. Results show that electricity use and peak powers are rising significantly when heat pumps are used, but better insulation level significantly decreases or even fully compensates the amount of additional electric power. The results can be used for the assesment of implications of extensive use of heat pumps to power grid.
\end{abstract}

\begin{tabular}{|ll|}
\hline \multicolumn{2}{|l|}{ Nomenclature } \\
EPBD & Energy Performance of Buildings \\
RF & Directive \\
HPI & reference values \\
SFH & high performance insulation values \\
TH & single family house \\
AP & terraced house \\
AWHP & apartment building \\
GSHP & air to water heat pump \\
DH & district heating \\
\hline
\end{tabular}

\section{Introduction}

It is common to use heat pumps as heat sources in single family and terraced houses. Heat pumps are also increasingly used in apartment buildings. Using heat pumps for main heat source helps to compliance with energy efficiency requirements.

The power and efficiency of air to water heat pumps decreases as the outdoor temperature decreases. Peak power is generally covered by an additional electric heater. As a result, power consumption increases significantly at low outdoor temperatures. Extensive installation of heat pumps can affect the operation of the electricity grid by generating an additional and unstable demand for electricity. Hourly power demand generated by heat pumps has been studied in [1] for renovated apartment buildings where switching from district heating to ground-source heat pumps was found to be an effective renovation solution in order to reduce emissions under current energy mix, but on the other hand this resulted in increased hourly peak electricity demand up to $153 \%$. Ground source heat pump was found to be one of the most cost-effective renovation measure in old apartment buildings [2].

The aim of this study was to find out the effect of application of heat pumps in new residential buildings on the hourly electricity power demand. Installation of ground source and air to water heat pumps were compared at two insulation level and in apartment builidngs also against the district heating. It was especially analysed how much the high performance insulation defined in the Finnish regulation [3] would allow to compensate the peak power effect of heat pumps compared to minimum insulation corresponding to the reference values. Five residential reference buildings were used in hourly energy simulations.

\section{Methods}

The energy demand of a building was calculated using the standard use of the building according to the calculation method in Finnish regulations [3].

\footnotetext{
*orresponding author: henri.sarevet@ ttu.ee
} 
The coefficient of performance (COP) and HP heating power was calculated for AWHP based on the outdoor temperature. GSHP COP and heat power were constant.

Need for additional electric power was calculated for new buildings. In the scenario analyses, for the construction volume of residential newbuild the following annual estimate was used for the next ten years:

- 7000 single family detached houses with average size of $112 \mathrm{~m}^{2}$,

- 3500 row house dwelling units with average size of $71.4 \mathrm{~m}^{2}$

- 25000 dwelling units in apartment buildings with average size of $55.8 \mathrm{~m}^{2}$.

This estimate is based on the average construction volume of recent years published in [4]. The average size of dwelling units of 2018 was used according to statistics of Finland [5].

\subsection{Weather data}

Energy consumption calculations are performed using the Helsinki-Vantaa test reference year.

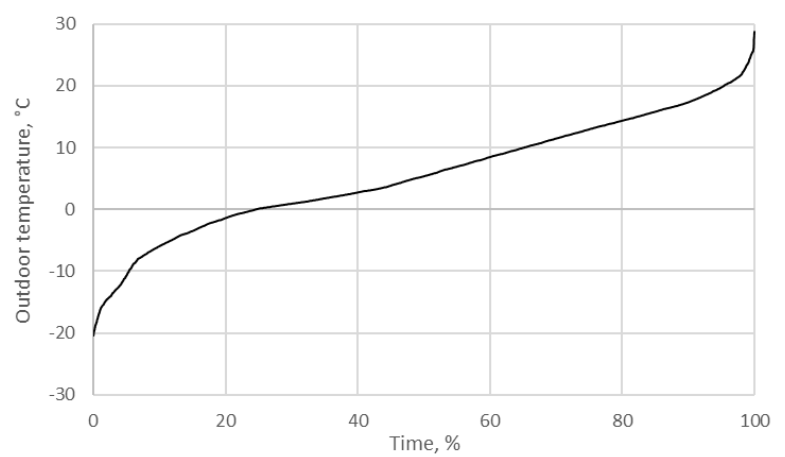

Fig. 1. Hourly mean outdoor temperature duration curve. Data from Helsinki-Vantaa TRY.

Design temperature for heating sizing was $-26^{\circ} \mathrm{C}$. Annual heating degree days at $\mathrm{t}_{\mathrm{i}}=17^{\circ} \mathrm{C} 3952^{\circ} \mathrm{C} \mathrm{d}$. The Finnish building code does not take into account the internal heat gains to estimate the design heat load.

\subsection{Reference buildings and heating solutions}

Three types of residential buildings were studied in order to cover all typical new residential buildings. Single family houses were represented by one small single storey and one two storey house. Similarly, apartment buldings were represented with one smaller and one large building.

The last reference building was a terraced house Overview of the specifications of the buildings is given in Tables 1, 2 and 3.

Table 2. Technical data

\begin{tabular}{|l|c|c|}
\hline & $\begin{array}{c}\text { Single family and } \\
\text { terraced houses }\end{array}$ & Apartment buildings \\
\hline $\begin{array}{l}\text { Heat recovery } \\
\text { ventilation supply } \\
\text { air reheating coil } \\
\text { type }\end{array}$ & electric & electric \\
\hline $\begin{array}{l}\text { Supply air } \\
\text { temperature, }{ }^{\circ} \mathrm{C}\end{array}$ & 18 & 18 \\
\hline $\begin{array}{l}\text { Room heating } \\
\text { system type }\end{array}$ & underfloor heating & radiators \\
\hline $\begin{array}{l}\text { Heating curve, } \\
{ }^{\circ} \mathrm{C} /{ }^{\circ} \mathrm{C}\end{array}$ & $40 / 33$ & $45 / 35$ \\
\hline $\begin{array}{l}\text { Heating set point, } \\
{ }^{\circ} \mathrm{C}\end{array}$ & 21 & 21 \\
\hline
\end{tabular}

Table 3. Finnish reference and high performance insulation Uvalues [3] and other input data

\begin{tabular}{|l|c|c|c|c|}
\hline \multirow{2}{*}{} & \multicolumn{2}{|c|}{$\begin{array}{c}\text { Single family and } \\
\text { terraced houses }\end{array}$} & \multicolumn{2}{c|}{ Apartment buildings } \\
\cline { 2 - 5 } & $\mathrm{RF}$ & $\mathrm{HPI}$ & $\mathrm{RF}$ & HPI \\
\hline $\begin{array}{l}\text { External wall, } \\
\mathrm{W} /\left(\mathrm{m}^{2} \mathrm{~K}\right)\end{array}$ & 0.17 & 0.12 & 0.17 & 0.14 \\
\hline $\begin{array}{l}\text { Roof, } \\
\mathrm{W} /\left(\mathrm{m}^{2} \mathrm{~K}\right)\end{array}$ & 0.09 & 0.07 & 0.09 & 0.07 \\
\hline $\begin{array}{l}\text { External floor, } \\
\mathrm{W} /\left(\mathrm{m}^{2} \mathrm{~K}\right)\end{array}$ & 0.17 & 0.1 & 0.17 & 0.1 \\
\hline $\begin{array}{l}\text { Window and } \\
\left.\text { door, } \mathrm{W} / \mathrm{m}^{2} \mathrm{~K}\right)\end{array}$ & 1.0 & 0.7 & 1.0 & 0.7 \\
\hline $\begin{array}{l}\text { Window Solar } \\
\text { factor }\end{array}$ & 0.55 & 0.46 & 0.55 & 0.46 \\
\hline $\begin{array}{l}\text { Air leakage rate } \\
\mathrm{q}_{50}, \mathrm{~m}^{3} /\left(\mathrm{h} \mathrm{m}^{2}\right)\end{array}$ & 4.0 & 0.6 & 2.0 & 0.6 \\
\hline $\begin{array}{l}\text { Ventilation rate, } \\
1 /\left(\mathrm{s} \mathrm{m}^{2}\right)\end{array}$ & 0.4 & 0.4 & 0.4 & 0.4 \\
\hline $\begin{array}{l}\text { Heat recovery } \\
\text { temperature ratio }\end{array}$ & $75 \%$ & $80 \%$ & $75 \%$ & $80 \%$ \\
\hline $\begin{array}{l}\text { Heat recovery } \\
\text { annual efficiency }\end{array}$ & $70 \%$ & $73 \%$ & $70 \%$ & $73 \%$ \\
\hline SFP, $\mathrm{kW} /\left(\mathrm{m}^{3} / \mathrm{s}\right)$ & 2.0 & 1.5 & 2.0 & 1.5 \\
\hline
\end{tabular}

Table 1. Specifications overview of the studied buildings.

\begin{tabular}{|l|c|c|c|c|c|}
\hline Building & SFH1 & SFH2 & AP1 & AP2 \\
\hline $\begin{array}{l}\text { 3D view of the } \\
\text { building model in } \\
\text { IDA-ICE }\end{array}$ & 1 & 2 & 506.7 & 1670.7 & 5 \\
\hline No of stories, - & 100.2 & 176.1 & 506.7 & 1670.7 & 5203.2 \\
\hline Net floor area, $\mathrm{m}^{2}$ & 176 & 1317.9 & 4532.1 & 5203.2 \\
\hline $\begin{array}{l}\text { Heater floor area, } \\
\mathrm{m}^{2}\end{array}$ & 100.2 & 455.4 & 907.7 & 2879.8 & 16608.9 \\
\hline Net cubature, $\mathrm{m}^{3}$ & 270.5 & 401.2 & 0.69 & 0.64 & 5874.1 \\
\hline $\begin{array}{l}\text { Envelope area, } \\
\mathrm{m}^{2}\end{array}$ & 325.6 & 0.88 & 18.7 & 25.1 & 0.35 \\
\hline $\mathrm{A}_{\text {envelope }} \mathrm{V}_{\text {net, }} \mathrm{m}^{-1}$ & 1.20 & 25.8 & 24.7 & 30.4 & 23.6 \\
\hline WFR, $\%$ & 19.2 & 21.9 & & & 39.0 \\
\hline WWR, $\%$ & 17.3 & & & \\
\hline
\end{tabular}




\subsection{Simulations}

Dynamic simulations are used to calculate the energy use of the building. The indoor climate and energy simulation program IDA-ICE 4.8 was used for the energy simulations.

Table 4. Standard use of the building [3]

\begin{tabular}{|l|c|c|}
\hline & $\begin{array}{c}\text { Single family and } \\
\text { terraced houses }\end{array}$ & Apartment buildings \\
\hline Occupant, $\mathrm{m}^{2} / \mathrm{per}$ & 42.5 & 28.3 \\
\hline Usage & 0.6 & 0.6 \\
\hline Lights, $\mathrm{W} / \mathrm{m}^{2}$ & 6 & 9 \\
\hline Light schedule & 0.1 & 0.1 \\
\hline Equipment, $\mathrm{W} / \mathrm{m}^{2}$ & 3 & 4 \\
\hline $\begin{array}{l}\text { Equipment } \\
\text { scedule }\end{array}$ & 0.6 & 0.6 \\
\hline $\begin{array}{l}\text { Ventilation } \\
\text { schedule }\end{array}$ & 1.0 & 1.0 \\
\hline
\end{tabular}

Heat pump and additional top-up heating element electricity consumption were calculated with postprocessing in Excel.

\subsection{Heat pump COP and heating power}

Air to water heat pump COP and heat output depends on the outdoor temperature. Depending on the heating system type the supply flow temperatures at design outdoor temperature were the following:

- underfloor heating $40^{\circ} \mathrm{C}$,

- radiators $45^{\circ} \mathrm{C}$,

- domestic hot water $55^{\circ} \mathrm{C}$.

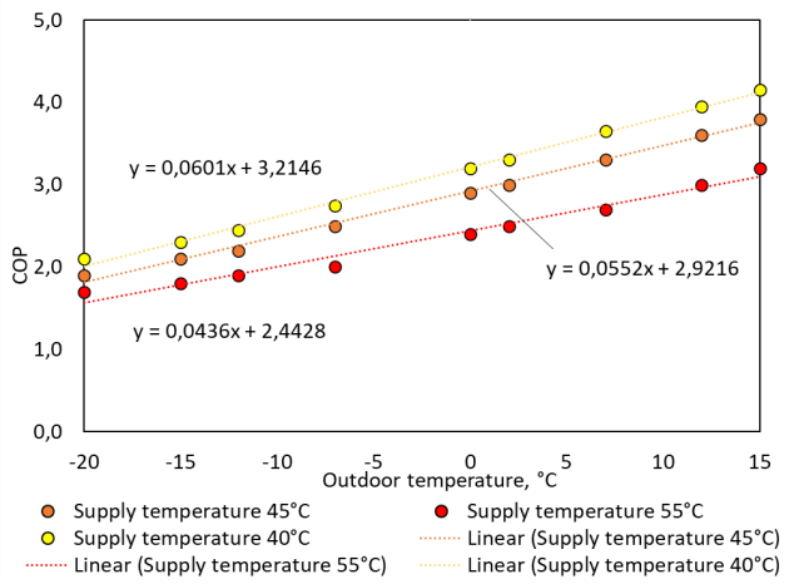

Fig. 2. AWHP COP equations as a function of outdoor temperature and heating curve

For the air to water heat pump a product specific performance map data was formalised to $\mathrm{COP}$ and heating power equations shown in Figures 2 and 3. COP depends on the supply flow temperature. The higher the flow temperature, the lower the COP. The heat pump was scaled for each building. In the calculations of single family and terraced houses HP nomimal heating power was $100 \%$ of heating load at design outdoor temperature. For apartment buildings, $70 \%$ of power sizing was used. This approach has been chosen to avoid overdimensioning. The extra cost of a powerful heat pump is greater than the savings.

\footnotetext{
${ }^{*}$ Corresponding author: henri.sarevet $@$ ttu.ee
}

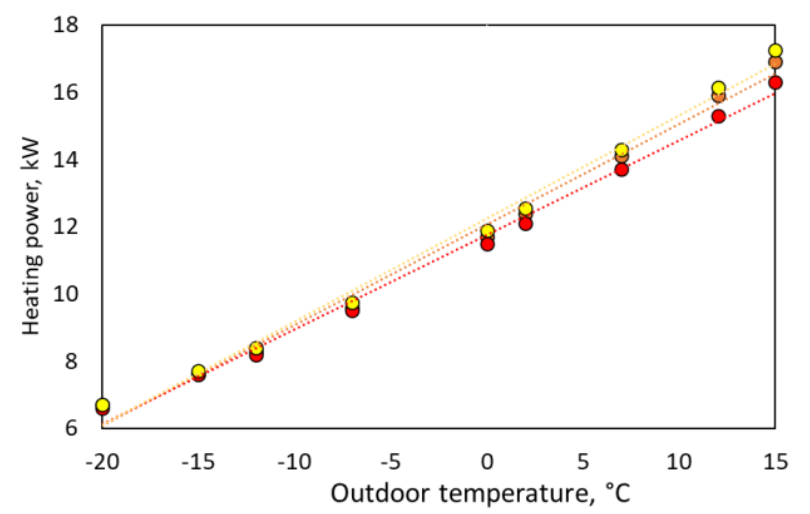

Fig. 3. AWHP heating power according to outdoor temperature

For the ground source heat pump the product specific average values of the coefficient of performance were used:

- ground source heat pump (heating system supply temperature $\left.40^{\circ} \mathrm{C}\right) \mathrm{COP}=4.21$,

- ground source heat pump (heating system supply temperature $\left.45^{\circ} \mathrm{C}\right) \mathrm{COP}=3.78$,

- ground source heat pump heating of domestic hot water $\mathrm{COP}=2.99$.

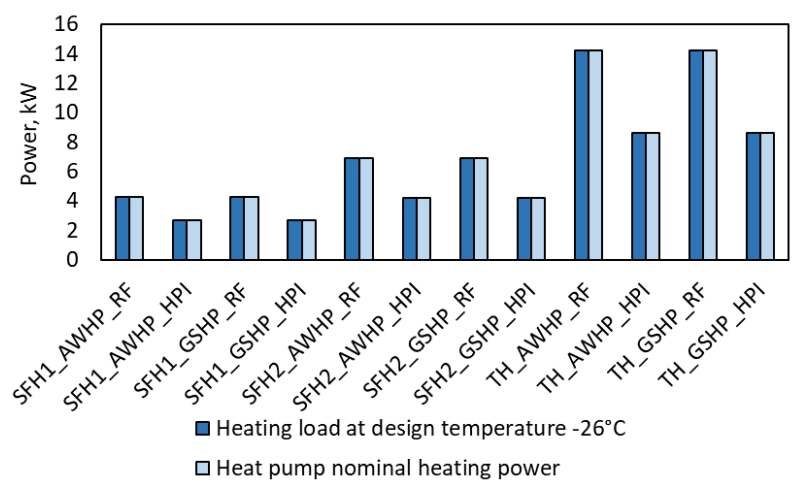

Fig. 4. Heating load at design temperature and heat pump nominal heating power

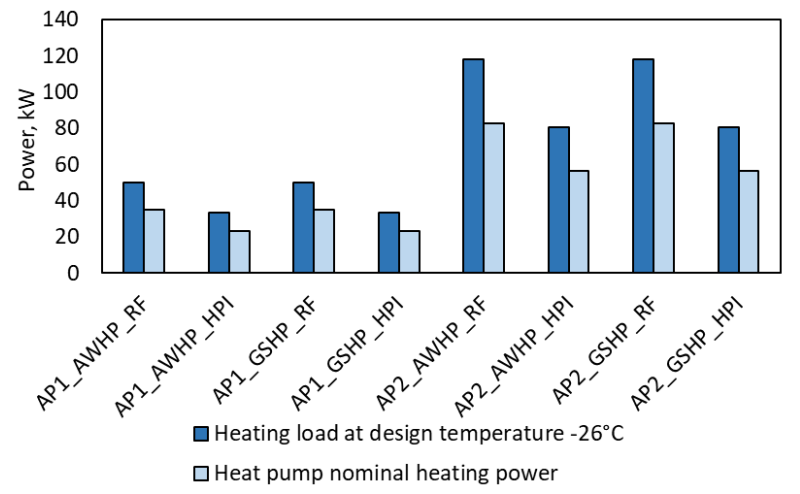

Fig. 5. Heating load at design temperature and heat pump nominal heating power 
Table 5. Heat pump Seasonal Coefficient of Performance

\begin{tabular}{|l|c|c|c|c|}
\hline \multirow{2}{*}{} & \multicolumn{2}{|c|}{$\begin{array}{c}\text { Single family and } \\
\text { terraced houses }\end{array}$} & \multicolumn{2}{c|}{ Apartment buildings } \\
\cline { 2 - 5 } & AWHP & GSHP & AWHP & GSHP \\
\hline $\begin{array}{l}\text { Room heating } \\
\text { system SCOP } \\
\text { includes } \\
\text { additional } \\
\text { heating) }\end{array}$ & $2.43-2.73$ & $3.51-3.79$ & $1.99-2.25$ & $3.73-3.78$ \\
\hline $\begin{array}{l}\text { Domestic hot } \\
\text { water system } \\
\text { SCOP }\end{array}$ & 2.62 & 2.99 & 2.62 & 2.99 \\
\hline Heat pump SCOP & $2.53-2.70$ & $3.16-3.54$ & $2.31-2.48$ & $3.11-3.34$ \\
\hline
\end{tabular}

\section{Results and discussion}

\subsection{Annual electricity need}

In single family and terraced houses with high performance insulation level annual total electricity consumption decreases by $21 \ldots 24 \%$ when using air to water heat pumps for heating in comparison minimum insulation level. Buildings with ground source heat pumps electricity consumption decreases $9 . .21 \%$.

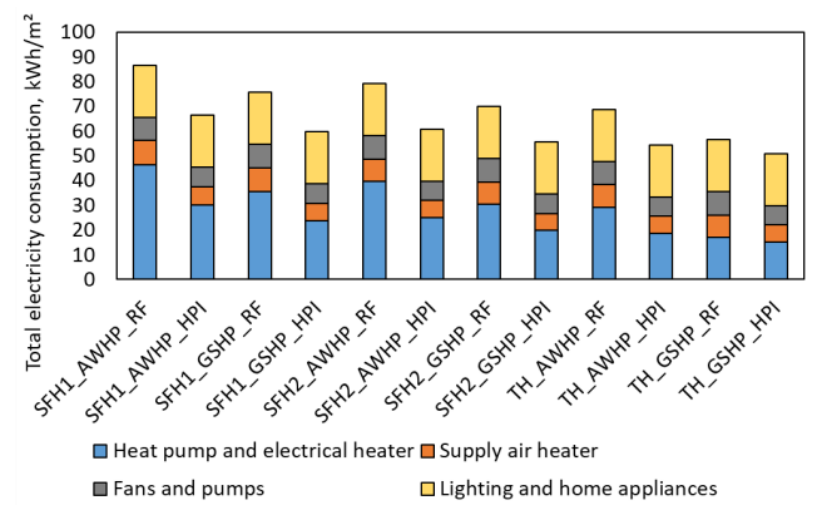

Fig. 6. Single family and terraced house annual electricity consumption

The energy consumption of apartment buildings decreased according to the heating source as follows:

- AWHP $14 \ldots 18 \%$,

- GSHP $8 \ldots 14 \%$,

- DH $8 \ldots 9 \%$.

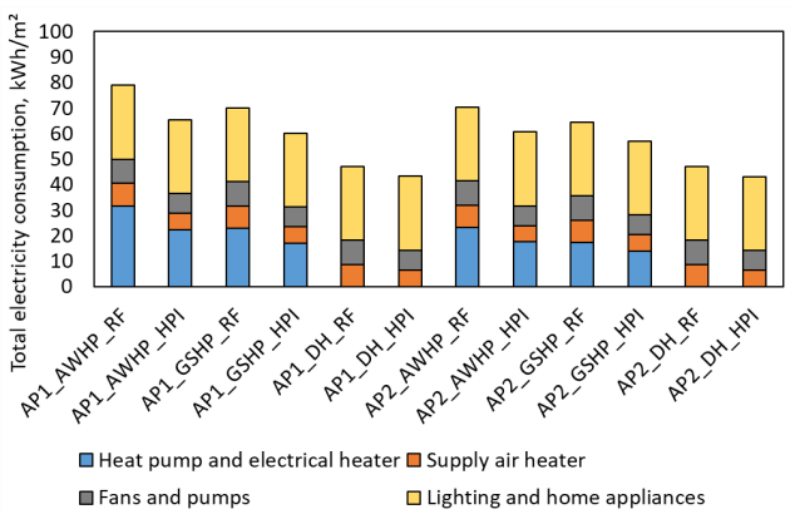

Fig. 7. Apartment building annual electricity consumption

\subsection{Hourly peak powers}

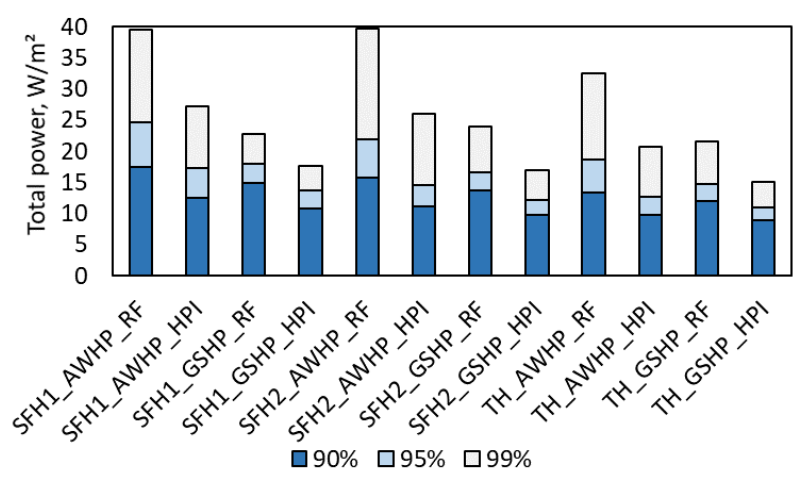

Fig. 8. Single family and terraced house total electricity power need

In single family and terraced houses using high performance insulation instead of minimum insulation, reduced electricity power need by $31 \ldots 36 \%$ for AWHP and by $23 \ldots 30 \%$ for GSHP.

Comparing apartment buildings with minimum insulation level and high performance insulation level, the total power need decreased by $-25 \%$ with AWHP and $-21 \%$ with GSHP.

When apartment buildings with heat pumps are compared with district heating, heat pumps increased peak electricity power need by :

- AWHP and RF +144\%,

- AWHP and HPI +83\%,

- GSHP and RF $+68 \%$,

- GSHP and HPI $+32 \%$.

This is due to the fact that the space heating and domestic water were supplied by heat pumps and additional top-up electrical heater.

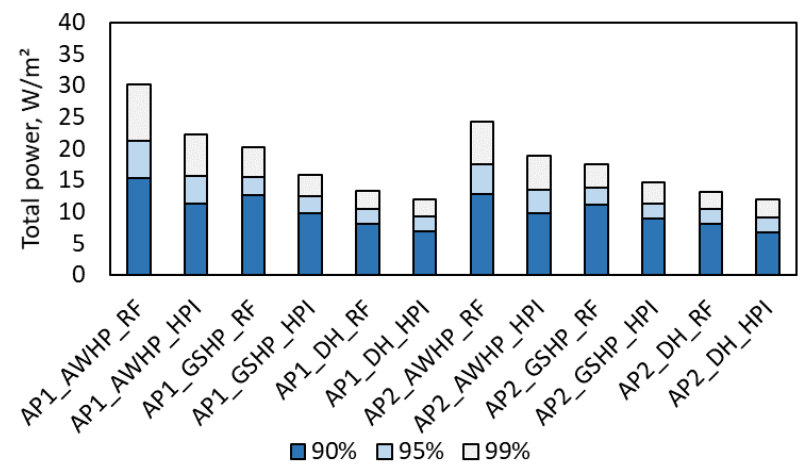

Fig. 9. Apartment building total electricity power need

\subsection{Need for additional electric power due to new construction}

This calculation takes into account the newbuild construction volume of 10 years. Three scenarios were simulated:

- minimum insulation level, apartment buildings with district heating, single family and terraced houses with heat pumps (reference scenario),

- minimum insulation level, all houses with heat pumps, 
- high performance insulation level, all houses with heat pumps.

It was assumed that $50 \%$ of installed heat pumps are AWHP and 50\% GHSP. Renovation and demolition were not considered in this scenario calculation.

Table 6. Need for additional electrical power for 10 years newbuild of residential buildings

\begin{tabular}{|l|c|c|c|c|}
\hline Scenario & $\begin{array}{c}\text { SFH, } \\
\text { MW/10y }\end{array}$ & $\begin{array}{c}\text { TH, } \\
\text { MW/10y }\end{array}$ & $\begin{array}{c}\text { AP, } \\
\text { MW/10y }\end{array}$ & $\begin{array}{c}\text { Total, } \\
\text { MW/10y }\end{array}$ \\
\hline $\begin{array}{l}\text { RF and district } \\
\text { heating }\end{array}$ & 419 & 144 & 214 & 777 \\
\hline RF and heat pumps & 419 & 144 & 442 & 1004 \\
\hline $\begin{array}{l}\text { HPI and heat } \\
\text { pumps }\end{array}$ & 333 & 91 & 337 & 760 \\
\hline
\end{tabular}

Scenario calculation shows that the electric power increase is lower when high performance insulation is used. Compared to the reference scenario (minimum insulation and apartment buildings with district heat), high performance insulation and heat pumps in all buildings resulted even in slightly lower additional electric power need. Therefore, the application of high performance insulation allowed to fully compensate the installation of heat pumps to apartment buildings.

\section{Conclusions}

The aim of this study was to determine the impact of extensive use of heat pumps as a main heat sources on the power grid. Application of high performance insulation reduced hourly peak powers by $13 \ldots 37 \%$ in different buildings relative to the minimum insulation. In apartment buildings, high performance insulation compensated about the half of additional electric power when buildings with heat pumps were compared to district heating. In the scenario calculation for residential newbuild for 10 years, the application of high performance insulation fully compensated the installation of heat pumps to all apartment buildings. This result depends on the proportion of heat pump types which was $50 / 50 \%$ for both heat pump types. Preference for ground source heat pumps over air to water heat pumps would further reduce the electricity power need. The results can be utilised for energy efficiency policy development and escpecially for the assesment of implications to power grid.

\section{Acknowledgements}

This research was supported by The Confederation of Finnish Construction Industries RT (CFCI) and by the Estonian Centre of Excellence in Zero Energy and Resource Efficient Smart Buildings and Districts, ZEBE (grant No. 2014-2020.4.01.15-0016) funded by the European Regional Development Fund.

\section{References}

[1] Janne Hirvonen, Juha Jokisalo, Juhani Heljo \& Risto Kosonen (2019): Effect of apartment building energy renovation on hourly power demand, International Journal of Sustainable Energy, DOI: 10.1080/14786451.2019.1613992

[2] Janne Hirvonen, Juha Jokisalo, Juhani Heljo \& Risto Kosonen (2019) Towards the EU emissions targets of 2050: optimal energy renovation measures of Finnish apartment buildings, International Journal of Sustainable Energy, 38:7, 649-672, DOI:

$10.1080 / 14786451.2018 .1559164$

[3] 1010/2017 Ympäristöministeriön asetus uuden rakennuksen energiatehokkuudesta https://www.ym.fi/fiFI/Maankaytto_ja_rakentaminen/Lainsaadanto_ja_ohjeet /Rakentamismaarayskokoelma/Energiatehokkuus

[4]The Confederation of Finnish Construction Industries RT, https://www.rakennusteollisuus.fi/Tietoa-alasta/Taloustilastot-ja-suhdanteet/Kuviopankki/Asuntomarkkinat/

[5] Official Statistics of Finland (OSF): Dwellings and housing conditions [e-publication]. ISSN=1798-6761. 2018, Appendix table 2. Floorarea per dwelling by type of building 1970-2018, whole dwellingstock. Helsinki: Statistics Finland [referred: 23.1.2020].

Access

method: http://www.stat.fi/til/asas/2018/asas_2018_2019 -05-14_tau_002_en.html 